\title{
JURISPRUDENCIA AMBIENTAL EN LA COMUNITAT VALENCIANA (PRIMER SEMESTRE 2017)
}

\author{
MARTA OLLER RUBERT \\ Profesora contratada doctora de Derecho Administrativo \\ Universitat Jaume I
}

Sumari: 1. Concessió minera. Sòl no urbanitzable de protecció paisatgística i ecològica (STSJCV 1047/2016, de 22 de desembre)

\section{CONCESSIÓ MINERA. SÒl NO URBANITZABLE DE PROTECCIÓ PAISATGÍSTICA I ECOLÒGICA (STSJCV 1047/2016, DE 22 DE DESEMBRE).}

En aquest afer es resol sobre la reclamació de responsabilitat patrimonial sol-licitada a l'Administració per l'empresa SIBELCO MINERALS CERAMICOS, SAU en haver-se qualificat l'àmbit de la concessió minera com a sòl no urbanitzable de protecció paisatgística i ecològica, després de l'aprovació del PGOU de Vilafames el 2013, i que va ser desestimada pel silenci administratiu de la Conselleria.

En efecte, la mercantil esmentada reclama a la Conselleria una quantitat econòmica en concepte d'indemnització pels danys i perjudicis causats per la declaració anterior que impedeix a l'empresa continuar amb l'activitat minera, per a la qual comptava amb una concessió minera des de l'any 1985. Arran de l'elaboració del projecte de PGOU del municipi de Vilafames, amb data de 10 de maig de 2000, es va publicar en el DOGV l'obertura del tràmit d'informació pública, moment que SIBELCO va presentar al-legacions a la proposta de qualificació com a "sòl no urbanitzable de protecció paisatgística i ecològica" i va sol-licitar les indemnitzacions oportunes. Després de l'aprovació del PGOU el 2003, es va interposar un recursos contenciós administratiu que els tribunals van desestimar, i es va confirmar la legalitat del PGOU de Vilafames. Després de plantejar-se diverses qüestions processals per la Conselleria demandada, com la prescripció de l'acció, que es desestima, i la falta de legitimació passiva davant la falta de competència de l'Administració 
autonòmica, que també es desestima, el Tribunal Superior de Justícia analitza si es compleixen o no els requisits per exigir responsabilitat patrimonial. En relació amb la protecció del medi ambient, és especialment rellevant el FJ vuitè, que analitza l'atribució de drets consolidables d'explotacions a partir de l'obtenció d'una concessió. En efecte, citant jurisprudència del Tribunal Suprem, es recorda que en el cas de concessions mineres han de conjugar-se els interessos ambientals i miners.

Finalment, el Tribunal Superior de Justícia entén que no concorren els requisits necessaris per reconèixer responsabilitat patrimonial, i desestima el recurs; en aquest cas, preval la protecció del medi natural. 